\title{
PENDAMPINGAN TEKNIK PEMBUATAN KERAJINAN TANGAN BERBAHAN DASAR SABUT KELAPA
}

\author{
Toni Pontien Mananti ${ }^{1}$, Ratmi Rosilawati $\mathbf{N}^{2}$ \\ Fakultas Pertanian Universitas Muhammadiyah Luwuk \\ Email : ratmi@unismuhluwuk.ac.id
}

\begin{abstract}
ABSTRAK
Kegiatan ini dilaksanakan pada tanggal 22 sampai 27 Februari 2017, bertempat di kantor Desa Lokotoy Kecamatan Banggai Utara Kerajinan sabut kelapa ini merupakan kegiatan wirausaha yang didasari dari kreatifitas pengrajinnya. Dengan memanfaatkan limbah sabut kelapa yang tidak terpakai, kemudian diolah menjadi benda kerajinan yang memiliki nilai jual. Usaha kerajinan dapat diartikan juga pengelolahan barang mentah atau setengah jadi dengan memadukan kemampuan dan keterampilan sehingga menghasilkan benda kerajinan sesuai harapan. Usaha kerajinan sabut kelapa ini sudah banyak dikenal diberbagai daerah dengan berbagai macam bentuk kerajinan yang dihasilkan dari sabut kelapa. Sebagai salah satu desa tujuan wisata, kerajinan tangan merupakan produk yang sangat potensial untuk dikembangkan karena produk tersebut dapat dijadikan sebagai ole-ole bagi wisatawan yang datang di desa tersebut.

Hasil Observasi yang dilakukan sampai saat ini, belum ada masyarakat di Lokotoy yang memanfaatkan sabut kelapa sebagai salah satu kerajinan tangan padahal bahan bakunya sangat banyak. Inilah yang menjadi pertimbangan kami mengangkat judul artikel ilmiah mahasiswa "Teknik pembuatan Kerajinan Tangan Barbahan Dasar Sabut Kelapa". Tujuan artikel ini adalah Meningkatkan keterampilan masyarakat dalam membuat kerajinan tangan berbahan dasar sabut kelapa dan tersciptanya kerajinan tangan berbahan dasar sabut kelapa yang dapat dijual untuk menambah pengahasilan keluarga.

Hasil analisis memperlihatkan bahwa (1) Tingkat pasrtisipasi masyarakat cukup baik, sehingga kegiatan yang dijalankan berjalan dengan lancar. (2) Pengetahuan dan keterampilan masyarakat dapat meningkat khsusnya dalam membuat keterampilan berbahan dasar sabut kelapa
\end{abstract}

Kata Kunci : Kerajinan, Sabut Kelapa

\section{PENDAHULUAN}

Kebutuhan semakin meningkat karena adanya pertumbuhan penduduk yang semakin berkembang dan peradaban yang semakin maju, maka timbul pikiran-pikiran untuk mencari bahan-bahan yang bisa diolah menjadi kerajinan. Dalam menciptakan kerajinan yang dapat dipasarkan, manusia harus pandai memanfaatkan sumber daya alam yang tersedia. Sumber daya alam yang dimaksud adalah segala benda yang ada di muka bumi ini baik berupa benda mati maupun makhluk hidup yang terdapat di suatu tempat.

Tidaklah berlebihan bila dikatakan bahwa sepanjang perjalanan hidup manusia tidak dapat melepaskan diri dari keterlibatan terhadap seni. Sejarah telah banyak membuktikan bahwa seni selalu seiring dengan perjalanan peradaban manusia, apalagi dalam kehidupan modern seperti sekarang ini. Fungsi seni terasa lebih kuat dan lebih berperan dalam kehidupan sehari-hari. Bendabenda yang diciptakan manusia difungsikan sebagai alat-alat untuk memenuhi kebutuhan hidupnya sehari-hari, dimulai dari benda yang kecil seperti sendok, alat makan, gelas minuman, dan rumah mewah semuanya itu diciptakan dengan mempergunakan pertimbangan-pertimbangan seni.

Kerajinan adalah hal yang berkaitan dengan buatan tangan atau kegiatan yang dihasilkan melalui keterampilan tangan (kerajinan tangan). Kerajinan yang dibuat biasanya terbuat dari berbagai bahan. Dari kerajinan inilah dihasilkan hiasan atau benda seni maupun barang pakai. Salah satu bahan yang dapat dimanfaatkan menjadi suatu kerajinan adalah sabut kelapa.

Kerajinan sabut kelapa ini merupakan kegiatan wirausaha yang didasari dari kreatifitas pengrajinnya. Dengan memanfaatkan limbah sabut kelapa yang tidak terpakai, kemudian diolah 
menjadi benda kerajinan yang memiliki nilai jual. Usaha kerajinan dapat diartikan juga pengelolahan barang mentah atau setengah jadi dengan memadukan kemampuan dan keterampilan sehingga menghasilkan benda kerajinan sesuai harapan. Usaha kerajinan sabut kelapa ini sudah banyak dikenal diberbagai daerah dengan berbagai macam bentuk kerajinan yang dihasilkan dari sabut kelapa.

Industri kerajinan sabut kelapa memiliki prospek masa depan yang baik karena potensi alam yang melimpah dan mempunyai tujuan untuk membangun kemandirian masyarakat. Berbagai barang yang bagus dan unik dapat dihasilkan dari sabut kelapa ini. Kreasi dari hasil kerajinan sabut kelapa yang didaur ulang menjadi sebuah kerajinan yang dipergunakan untuk keperluan sehari-hari seperti sapu, pot bunga, kursi dan barang kerajinan lainnya.

Selain untuk menambah pendapatan keluarga, industri kerajian dapat membantu terbukanya kesempatan kerja baru bagi masyarakat lain. Sehingga sangat banyak manfaat yang didapatkan dari suatu usaha kerajian tangan. Desa Lokotoy merupakan desa yang terletak di wilayah Kecamatan Banggai Utara dan masyarakatnya banyak yang berpropesi sebagai petani. Usahatani yang banyak dijalankan oleh masyarakat di Desa Lokotoy salah satunya adalah usahatan Kelapa Dalam. Usaha tani kepala dalam yang dijalankan diolah menjadi produk kopra, dari hasil olahan tersebut terdapat bahan baku sabut kelapa yang selama ini hanya dijadikan oleh masyarakat sebagai bahan bakar pengasapan kelapa (Kopra). Padahal masih banyak produk olahan lain berbahan dasar sabut kelapa yang nilainya lebih tinggi dibandingkan hanya dibakar. salah satunya adalah produk kerajinan tangan berbahan dasar sabut kelapa seperti Pot Bunga.

Sebagai salah satu desa tujuan wisata, kerajinan tangan merupakan produk yang sangat potensial untuk dikembangkan karena produk tersebut dapat dijadikan sebagai ole-ole bagi wisatawan yang datang di desa tersebut. Hasil Observasi yang dilakukan sampai saat ini, belum ada masyarakat di Lokotoy Dua yang memanfaatkan sabut kelapa sebagai salah satu kerajinan tangan padahal bahan bakunya sangat banyak. Inilah yang menjadi pertimbangan kami mengankat judul artikel ilmiah mahasiswa "Teknik pembuatan Kerajinan Tangan Barbahan Dasar Sabut Kelapa".

\section{TUJUAN}

Tujuan dari artikel ilmiah adalah :

1. Meningkatkan keterampilan masyarakat dalam membuat kerajinan tangan berbahan dasar sabut kelapa.

2. Tersciptanya kerajinan tangan berbahan dasar sabut kelapa yang dapat dijual untuk menambah pengahasilan keluarga.

\section{METODE}

\section{Waktu dan Tempat Pelaksanaan Observasi}

Observasi kegiatan dilakukan mulai tanggal 29 - 30 Agustus 2017. Observasi di lakukan di Desa Lootoy dusun. Observasi dilakukan dengan cara melakukan wawancara dengan beberapa masyarakat petani dan pemerintah desa serta anggota BPD. Dari hasil waancara didapatkan informasi tentang potensi pengembangan kerajinan tangan berbahan dasar sabut kelapa.

\section{Waktu dan Tempat Pelaksanaan Kegiatan}

Kegiatan ini dilaksanakan pada tanggal 22 sampai 27 Februari 2017, bertempat di kantor Desa Lokotoy Kecamatan Banggai Utara.

\section{Alat dan Bahan}

Adapun Alat dan bahan yang digunakan dalam proses pembuatan kerajinan tangan berbahan dasar tempurung kelapa adalah :

1. Limbah Sabut Kelapa

2. Pisau

3. Kertasi Pasir

4. Cat

5. Pernis 


\section{Bunga}

7. Rotan

\section{Prosedur Kerja}

Prosedur kerja kegiatan yang dilakukan meliputi:

1. Mengidentifikasi ketersediaan bahan baku sabut kelapa

2. Menyiapkan sabut kelapa yang akan dijadikan kerajinan tangan

3. Mempersiapkan peralatan yang dubutuhkan dalam membuat kerajinan tangan.

4. Melakukan rapat persiapan dengan masyarakat sasaran pengabdian

5. Mengidentifikasi produk kerajinan yang akan dibuat

6. Pendapingan Pembuatan produk kerajinan tangan berbahan dasar sabut kelapa

\begin{tabular}{|c|c|c|c|}
\hline $\begin{array}{c}\text { Tahapan } \\
\text { Pelaksanaan }\end{array}$ & Kegiatan & Metode & Materi \\
\hline \multirow[t]{3}{*}{ Pelaksanaan } & $\begin{array}{l}\text { Sosialisasi ke } \\
\text { Masyarakat sasaran }\end{array}$ & $\begin{array}{l}\text { Pertemuan dengan } \\
\text { masyarakat Sasaran }\end{array}$ & $\begin{array}{ll}\text { - } & \text { Menyamakan Persepsi } \\
\text { - } & \text { Menetukam Program- } \\
& \text { Program yang akan } \\
& \text { dilaksanakan } \\
\text { - } & \text { Menentukan waktu } \\
& \text { Pelaksanaan Kegiatan }\end{array}$ \\
\hline & $\begin{array}{l}\text { Penyiapan Alat dan } \\
\text { Bahan }\end{array}$ & $\begin{array}{l}\text { Mengumpulkan } \\
\text { Alat Dan Bahan } \\
\text { Yang dibutuhkan } \\
\text { dalam kegiatan }\end{array}$ & 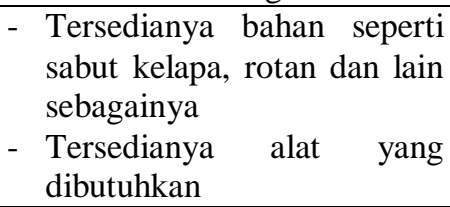 \\
\hline & Palaksanaan & Partisipatif & $\begin{array}{ll}\text { - } & \text { Mengumpulkan masyarakat } \\
& \text { sasaran } \\
\text { - } & \text { Melakukan kegiatan }\end{array}$ \\
\hline
\end{tabular}

\section{HASIL DAN PEMBAHASAN}

Sabut kelapa yang dibuat menjadi kerajinan seperti Pot Bunga, keset dan lain-lain. Dengan sentuhan seni yang halus, Sabut kelapa tersebut akan kelihatan lebih cantik, lebih artistik dan sangat menarik. Dibawah ini beberapa beberapa contoh kerajinan tangan dari sabut kelapa yang sederhana tapi memiliki nilai jual yang tinggi.

Kegiatan pelatihan pembuatan kerajinan tangan berbahan dasar sabut kelapa dilakukukan dengan tujuan untuk memberikan pemahaman kepada seluruh masyarakat bahwa pemahaman selama ini yang ada dalam diri mereka bahwa bahan seperti sabut kelapa hanya berakhir menjadi kayu bakar ataupun sampah yang tidak berguna lagi dapat dibuat mejadi produk yang benilai ekonomi dan membantu peningkatkan pendapat keluarga.

Dalam pelaksanaan kegiatan dilakukan dengan beberapa tahapan mulai dari sosialisasi, pengumpulan alat dan bahan, pelaksanaan kegiatan. Berikut ini uaraian dari setiap tahapan kegiatan yang dijalankan.

\section{A. Tahapan Sosialisasi}

Kegiatan sosialisasi ini dilaksanakan pada bulan februari 2017 tepatnya pada tanggal 20 Februari 2017. Bertempat di balai desa Lokotoy kecamatan Banggai Utara Kabupaten Banggai laut. Tujuan dari kegiatan ini adalah untuk memberikan pemahaman awala kepada seluruh masyarakat sasaran tentang kegiatan yang akan dilaksanakan dan manfaat yang didapatkan jika mengikuti kegiatan ini. Sehingga dengan cara demikian diharapkan dapat meningkatkan minat masyarakat untuk ikut terlibat dalam kegiatan ini

Dalam pelaksanaan sosialisasi ini tidak ditemukan kendala yang berarti oleh karena masyarakat sasaran sangat antusias dalam mengikuti kegiatan ini dan partisispasinya cukup baik. 
Dengan pastisipasi yang cukup baik membuat pelaksanaan kedepannya akan semakin mudah karena masyarakat telah mendapatkan gambaran awal tentang kegiatan.

Selain tiu dalam tahapan ini ditentukan pula waktu pelaksanaan dan proses-proses yang akan dilalui nantinya selain itu ditetapkan pula produk kerajinan yang akan dibuat dalam pelatihan tersebut. Setelah kesepakatan terwujud antara mahasisiwa pelaksana dan masyarakat sasaran maka program kegiatan dapat dilanjutkan pada tahapan berikutnya.

\section{B. Tahapan Penyiapan Alat dan Bahan}

Penyiapan alat dan bahan bertujuan agar dalam pelaksanaan kegiatan nantinya masyarakat sasaran tidak sibuk lagi mencari-cari bahan dan alat yang dibutuhkan. Sehingganya memudahkan dalam pelaksanaan kegiatan nantinya. Dalam tahapan ini perlu untuk disyukuri karena bahan baku sangat mudah didapatkan oleh karena bahan bakunya sangat banyak tersedia disekitar desa bahkan selama ini bahan baku yang dibutuhkan tersebut hanya diangga sebagai sampah bagi masyarakat sehingga tidak termanfaatkan.

Beberapa alat dan bahan yang disediakan antara lain yaitu sabut kelapa, rotan, pernis, kertas pasir, cat, pisau dan bunga sebagai bahan yang akan diletakan pada media pot yang akan dibuat nantinya.

\section{Pelaksanaan Teknik Pembuatan Kerajinan Tangan Berbahan Dasar Sabut Kelapa}

Pelaksanaan pembuatan Kerajinan Tangan Berbahan Dasar Sabut Kelapa dilaksanakan selama lima hari dengan menghadirkan seluruh masyarakat sasaran dalam hal ini masyarakat desa lokotoy. Pelatihan dilakukan mulai dari menyiapkan bahan. Setelah suluruh bahan sudah siap maka langkah selanjutanya membuat kerajianan pot bunga berbahan dasar sabut kelapa. Berikut ini gambar produk yang dihasilkan.
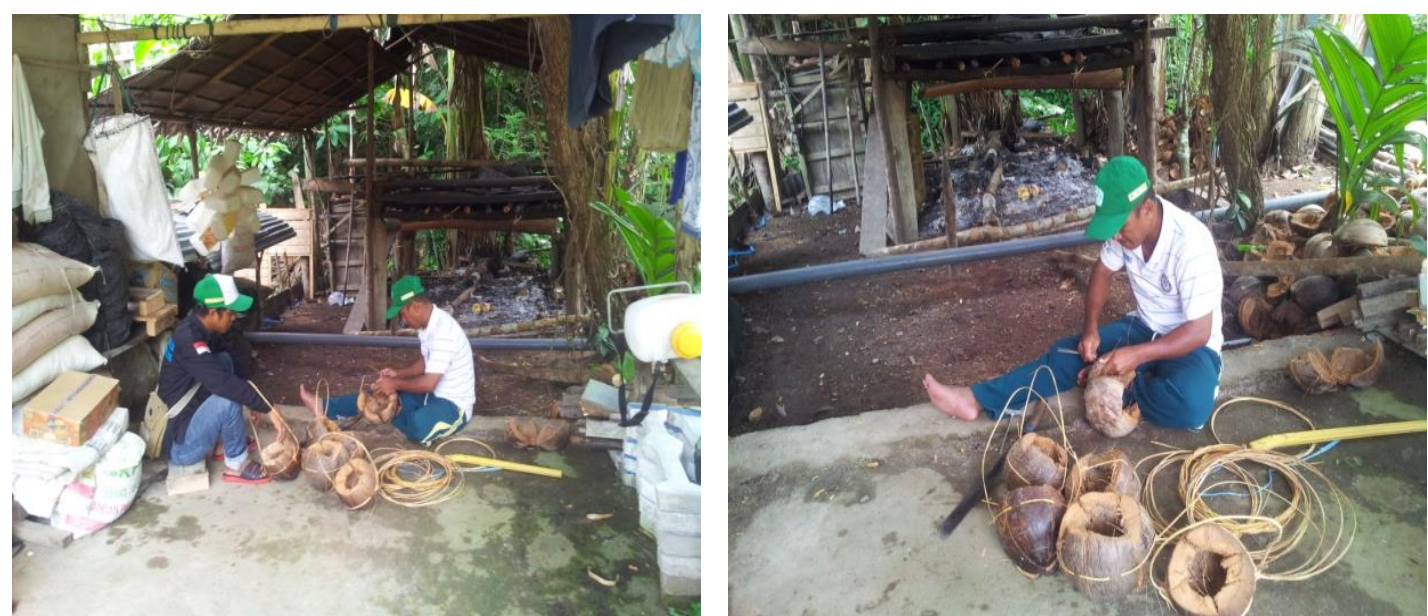

Gambar 1. Kegiatan Pembuatan Kerajinan Tangan Berbahan Dasar Sabut Kelapa

Pelatihan yang dilakukan memberikan manfaat bagi masyarakat sasaran berupa peningakatan pengetahuan dan keterampilan masyarakat dalam membuat kerajianan bebahan dasar sabut kelapa.sehingga kedepannya diharapkan mayarakat mampu memanfaatkan potensi yang ada disekitar mereka untuk membantu meningkatkan perekonomian mereka.

Dalam pelaksanaan kegiatan perlu disyukuri bahwa mahasiswa pelaksana tidak menemukan kendala yang berarti sehingga kegiatan yang dijalankan berjalan dengan lancar dan selesai sesuai dengan harapan. Hal ini dikarenakan partisipasi masyarakat yang sangat tinggi dan baik. 


\section{KESIMPULAN}

1. Tingkat partisipasi masyarakat cukup baik, sehingga kegiatan yang dijalankan berjalan dengan lancar.

2. Pengetahuan dan keterampilan masyarakat dapat meningkat khususnya dalam membuat keterampilan berbahan dasar sabut kelapa

\section{DAFTAR PUSTAKA}

Anonim (2000). Hasil pengkajian sabut kelapa sebagai hasil samping . Jakarta: Bank Indonesia.

Nur, I. I., Kardiyono, U., \& Aris. A. (2003). Pemanfaatan limbah debu sabut kelapa dalam usaha tani padi pasang surut. Kelembagaan Perkelapaan di Era Otanomi Daerah. Prosiding Konferensi Nasional Kelapa V. Tembilahan, 22 - 24 Oktober 2002. 